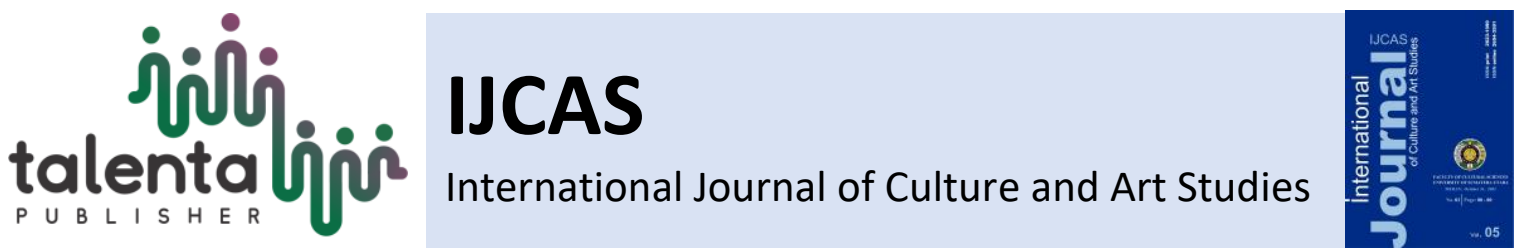

\title{
Different Understanding about the Other Shore: the Introspection Study on Chinese and Western Art under the Natural Disaster
}

\author{
Sun Zhi-hao* \\ Suzhou University of Science and Technology, College of Art, Suzhou, China.
}

\begin{abstract}
No matter what the different cultural backgrounds are, they will always collide and generate divergence on the same point of intersection and then continue moving forward in the direction of collective cognition. At present, the global world is facing severe pestilence disasters; China Art Circle made many responses immediately at the beginning of the epidemic situation and tried to fight the epidemic situation, encourage the front-line medical staff and provide energy for them. However, when the epidemic situation in China trends to calm, the art theme about the epidemic situation also suddenly keeps silent. It looks like calm without great waves; however, through investigating Western art, it is found that the Western Art Circle has different orientations on the attitude to disasters; considering its inner core, it maps the further understanding of groups with different cultural backgrounds on the cognition of other shores of life- different life and death idea influence the social outlook, view of life and expectation of life fate of different groups. Meanwhile, they also promote the society to show different introspection paths while facing disasters. The study uses empirical analysis to identify and collect the image information from classical paintings of the East and the West. The results show that compared with Western art, Chinese art conveys a message that focuses more on maintaining the country's stability.
\end{abstract}

Keywords: Art, Chinese culture, Introspection, Life and death, Pestilence

Received 12 August 2021 | Revised 24 August 2021 | Accepted 26 October 2021

\section{Introduction}

Art cannot directly turn around the track of natural disasters- certainly, it is not the responsibility of art; however, art is undoubtedly helpful for us to change our attitude to natural disasters. Art and society are like two sides of metal fragments that cannot be separated. Art cannot be separated from social life in that literature has the power to express and imagine pain and oppression or everything about an imbalance in social life (Askar, 2021). The creation of Chinese and Western Art shows different thought directions while facing disasters. At present, global people suffer from the epidemic situation, and through art, whether the public could recognize the disaster, scientifically overcome the disaster and do deeper thinking from a wider view to promote harmonious social order in the future, promote the society to a healthier and more orderly direction is the mission of art. In China's current diversified art form (especially the art form

\footnotetext{
${ }^{*}$ Corresponding author at: Sun Zhi-hao, lecturer, Suzhou University of Science and Technology, College of Art, Suzhou, 215163, People's Republic of China. 
mainly includes easel art), art expression is influenced by many factors, which cause its track to be different from the expression of Western art. There is the deviation of gene inheritance of different nation blood, which brings a different attitude to the epidemic situation and makes introspection and introspection. This process naturally has transcendence, insufficient, and defects.

\section{Expression and Cultural Backgrounds of Chinese and Western Art on Different Understanding about Disasters}

Looking through history, the living environment of human beings is always together with the fight against nature, the fight against diseases and fight among people, the plague in the Middle Ages and other pestilences brought huge disasters to the continent of Europe, and these disasters killed countless people's lives, including some well-known artists. Disasters make people generate a sense of fear; no matter what kind of disaster, the force of art and literature is extremely poor in front of them. However, the values of art and literature and always induce people to think about previous events deeply. That is to say, art also carries its valuable potential energy in disasters, not the narcissistic Soratani Orchids, and disaster culture is also a self-rescue culture for the human to survive is essential (Tang, 2011). The description of disasters is also the "culturalization" of disasters, and it transfers the destructive power of nature to the social culture as the energy of art creation (Zhang \& Song, 2018, p.160).

At present, the Covid-19 transmits all over the world, and the epidemic situation threatens life. At the beginning of the epidemic, the invisible enemy, like a ghost, brought a scared psychological shadow to the public. But as time flies, viral spreading gradually trends to preventable, controllable and curable, so the virus is not mysterious and scary. But we shall note that, even like this, the global world still faces a rigorous epidemic situation.

Compared with the psychological change brought by the epidemic situation from the random expansion to the controlled condition to people "scared-optimistic," China Art Circle also changed greatly. At the beginning of the epidemic situation, all local atheneum, communities, colleges, and universities actively organized art exhibitions related to the epidemic situation (most of them are online exhibitions). At that time, all people could find through the internet that some famous Chinese infectious disease experts were just like avatars, and they fought against the virus by several unimaginable means. Many kinds of art creations emerge with a blowout manner, including many works with low art levels and without corresponding thinking, but Chinese people did not care about this. These works had the same topic- "win the virus." At that time, the artistry of artworks became unimportant. Even if they are images and literal works, if their directions were correct and had image and transmissibility, they could be referred to as "art" (see Figure 1

, Figure 2). 

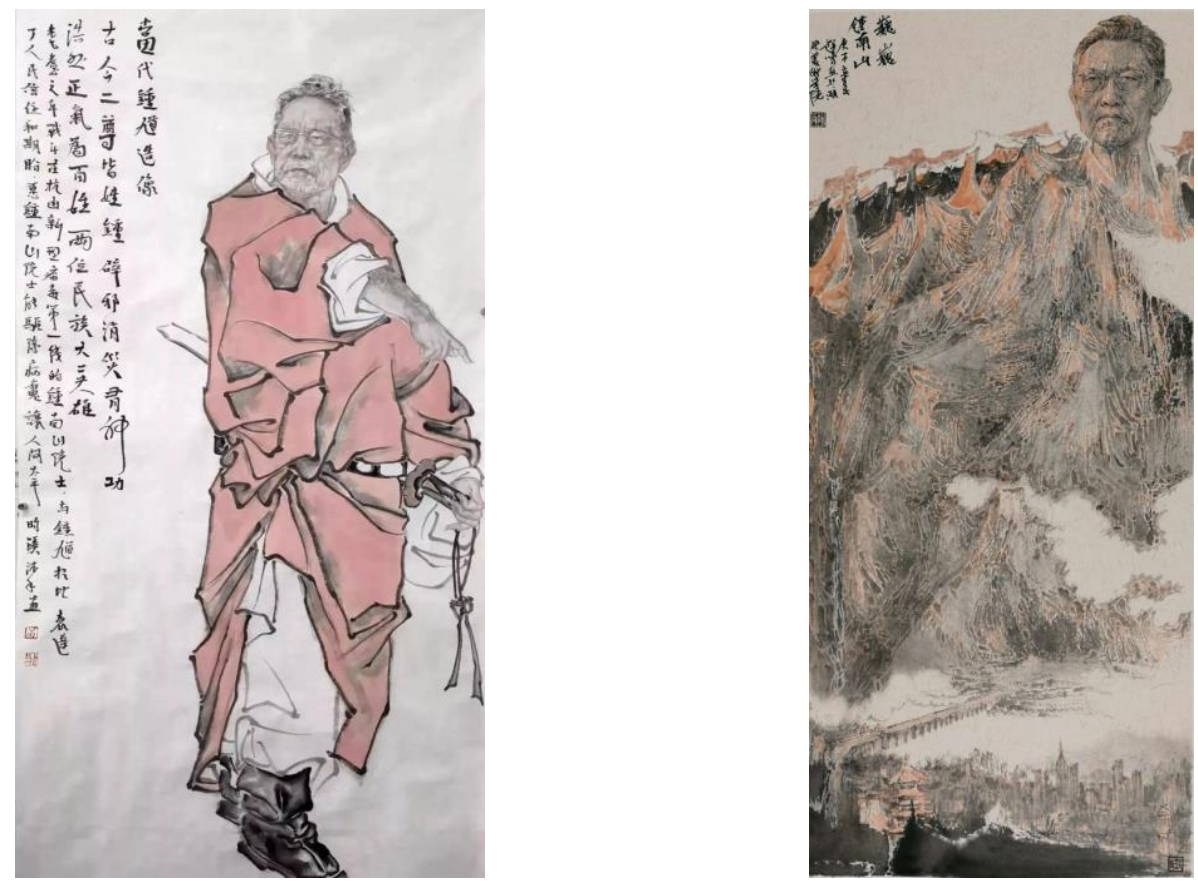

Figure 1. Li Yunxi, Image of Modern Zhong Kui Figure 2. Wei Wei, Image of Zhong Nanshan

The cognition of human beings on death exhibits the colour of keeping up with the times with the development of times and transition of traditional regional culture, which enables the attitude and thought of human beings while facing disasters to change continuously, just as it is described by Cassirer in An Essay on Man that, the estrangement of different fields does not make changeless, and changes with the paroxysmal external change (Cassirer, 1985, p.104). In the history of the world, the enforcement of the funeral policy of a king, the new explanation of a school of philosophy, a heroic act representing the collective consensus and giving up the opportunity of survival, and so on, are causing the public to express their views on death. Therefore, when the public face the death threatens brought by disasters, their thoughts also change gradually.

Confucianism, Buddhism, and Taoists influence the important thinking of life and death in Chinese traditional culture. The Confucianists consider that the human existence can surpass the life limit, i.e. pursuing a "immortal" state, and consider in the Commentary of Zuo Xianggong 24th Year that "the Lord is with moral composition, the second is with performance, and then with the speech, although it has passed a long time, it has not been abandoned, so it is called immortal." (Li,2011) Confucianists consider that spirits can surpass the body with a terminal and reach the eternal and immortal state. This process is manifested through merits, words and deeds, which requires people to perform the due social responsibilities while facing death. It can be seen that it relates to the exploration of human fate and life meaning, and human life's physical property termination cannot limit the continuity of spirits. Therefore, required by kindheartedness, justice, morality, and sacrifice justice, such as the national heroes Wen Tianxiang, Shi Kefa, and Zhang Huangyan are remembered and become rich educational events. Taoists emphasize complying with the law of nature and assert that people shall calmly face any disaster, i.e. disaster 
is also one link of the law of nature. Human beings are just a small part of everything in the universe. If put human life in the view of space and nature, it enables people to stand on a wide platform while observing the word, surpassing the reluctance of individual life and death while encountering disasters to consider human value. In this way, they can be calm and fearless while facing disasters and death. Buddhism has many sections, and as the most influential representative, Zen has already run through every aspect of life, such as the most familiar words in daily life: worry, retribution and cause. When humans face disasters, Zen emphasizes selfdiscipline, monitoring self and self-examination, and saving the world's hardship with the attitude of taking across sentient beings universally. Through the analysis, comparison and conclusion, the most representative thought of Confucianism, Buddhism and Taoists in Chinese traditional culture, no matter what kinds of thinking ways, their final fates always point to collectivity, even a macroscopical universe, not advocate individual benefit, gain and loss. However, in the Western culture, religion carries the significant core of wisdom of people. While facing disasters, what needs to emphasize is to examine whether the previous events follow the benchmarking established by religions, through "correction" behaviours, enable individuals to close up the ideal model and obtain a better fate in the judgement of the world on the other shore.

Facing the Chinese and Western cultural backgrounds, they own similar feedback while facing disasters, but there is some difference between the agent and expectation of introspection; Eastern culture emphasizes more of a collective idea of "entry the world", more wills to treat the relationship between people and between the people and the collectivity.

On the contrary, western civilization trends to the individual idea of "birth", trends more mapping the behaviours in the world as chips to the position of the other shore.

\section{Cultural Difference Reflected by Two Senses of Heroes.}

Art is a mirror of reality, and as the prelude of art practice, the thought enables Chinese and Western Art to take the mastering position in the Eastern art using the different formulation, collective belief and honour; however, in Western art, no matter the religious art of the Middle Ages or the Modernism art, they prefer to express an individualized and perfect ideal body weight, it often likes this even if in a grand narration theme. But such a phenomenon is rooted in the difference of the cognition of Eastern and Western publics on "heroes" (under the Western cultural background, it is more suitable for here to be referred to as "the Saviour").

It is undeniable that heroes play a critical role in the advancement and transformation of society: on the one hand, they change the objective world through their strong practical ability; on the other hand, they influence their followers through their unique spiritual charm. Chinese and Western views on heroes are influenced by different histories and shaped into different spiritual orientations: to be exact, the understanding of Chinese people about heroes since ancient times is 
an idealized collective consensus rather than a specific natural figure; on the contrary, western people are more sure that a specific figure has played a role in promoting the process of history.

Compared with the heroes created in the Western, Chinese heroes have different meanings. Chinese heroes have morally oriented preaching significance, perfectionist characterization method, the experience of tragic tendency, the colour of depersonalization, and praise message given by official rights. On the other hand, the Western views of heroes show the characteristics of individuation (even defect), life supremacy, independence and folk (Li,2012). In conquering disasters, it is easy to achieve outstanding contributions, be remembered by the public and rise to the heroic height of saving the collective. The perfect image of Chinese heroes has a certain ideal colour. This is because heroes should not have flaws. Otherwise, they will be considered as the blasphemy of the image of upright and tall. Therefore, when remoulding historical heroes, we shall beautify their flaws and keep a certain distance from the public to highlight the perfect attribute of heroes. For example, historical figures moved to the screen are always moulded and created as a hero image of hatred of evil, benevolence and justice, even if they have a strong sense of deviation from the real historical records. The heroes in various art forms are based on positive fragmentary historical information, making more dramatic rendering. They appropriately add some minor "defects" that are irrelevant and easy to accept to make the shaping of human nature more vitality.

In other words, as special individuals, heroes are supposed to have paranoia at a certain point of interest. This is the perfect requirement of China for heroes to make the image of the characters vividly. For example, Wen Tianxiang stood for patriotism, Qu Yuan stood for the honest and noble character, Lei Feng stood for selfless dedication as a party member. Behind these characters is an invisible vein full of guiding educational significance. The deeds of heroes are endowed with the colour of official rights because the official holds public communication resources. However, there is a deviation between the official and public heroes in their cognition and needs. Excessive deification and elevation of the heroes images make the public misunderstand the heroes, which easily lead to a result that the heroes have no themselves but are a kind of heroes with an embodiment of collective honour and disgrace. Although a Chinese hero appears in the name of a character, it is not a specific name, a title or a story, but trust in the collective interests and rights and the will to safeguard the country. Therefore, when a disaster occurs, the object that the public expects is not personal power to turn the world around but an abstract body of benevolence and morality to redeem. It is a trust in the collective and the country to attach this ideal and belief to one or several special people because, for a long time, the official always represented an ideal moral paradigm.

In contrast, in the process of hero shaping in the west, because of its distinctive characteristics of populism, personalization and independence, every citizen thinks that heroes are born around him, and even he can become a hero. Therefore, when a disaster occurs, the public tends to rely on his 
own strength to maintain practical interests, which requires everyone to have an individual personality when facing emergencies. It is not difficult to find cases in Western literary works with accurate judgment and timely and effective response-ability. In short, in the face of disaster, Chinese people are more likely to obtain inner peace, which has a certain subjective colour, because the Chinese people will think that behind them stands collective protection, so Chinese heroes often come from extraordinary origins; At the same time, in the west, it is easier to activate the strength of each unit, and then promote the emergence of "civilian" heroes.

\section{Information Hidden in Chinese Disaster Art}

There is a deviation in the judgment of heroes, which makes the direction of artistic expression different. Facing a disaster, Chinese and Western artists think in different directions. It is not difficult to find that catastrophic narrative has been in the state of "absence" for a long time in Chinese Art. Even if there is a description of a disaster, it is often from the perspective of the upper class overlooking the masses at the bottom. This is different from western art. In Western art, people's powerlessness is reflected by describing the destructive power and fear of disaster. It seems that in China, artists deliberately avoid the disaster itself and tend to use the disaster to depict dedication, patriotism and collective consciousness, depicting the disaster as a grand narrative to achieve the requirements of cohesion of the public centripetal force. Therefore, they will consciously weaken the appearance of the disaster and further highlight the heroes' excellence.

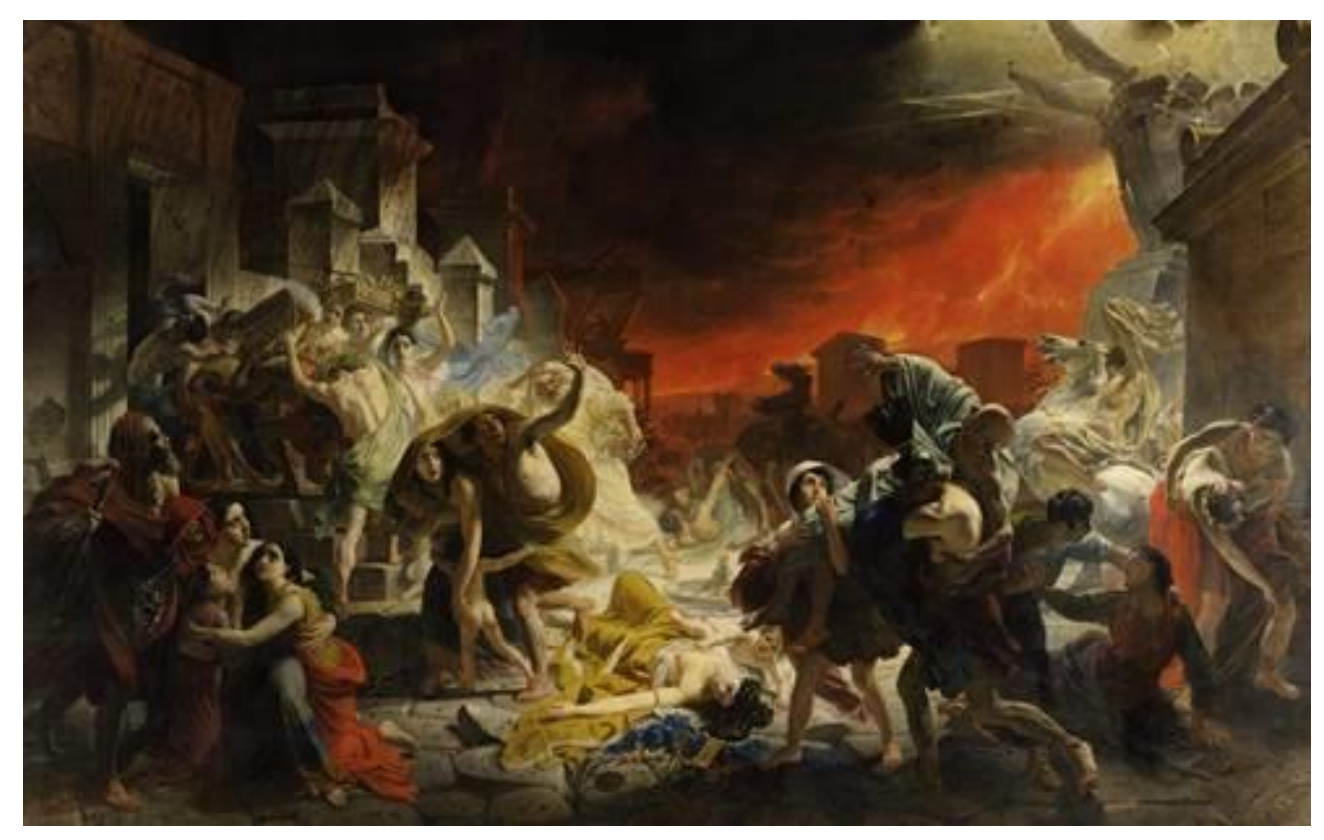

Figure 3. Karl Pavlovich Bryullov, Pompeii Doomsday 
In the Russian painter Karl Pavlovich Bryullov's Pompeii Doomsday (Fig. 3), the viewers can feel that when the disaster comes, the human power is unable to resist the changes of nature. The fallen buildings, the trembling and frightened crowd, the frightened horses, lightning, and fire penetrate the rolling smoke in the distance. They are approaching, indicating that Pompeii City is a harbinger of disasters. Fear, uneasiness, anxiety and despair pour out wantonly in the picture, rendering the doomsday scene deeply rooted in the people's hearts. It seems that in the face of nature, all the benevolence, compassion and justice are pale and powerless; there is no Redeemer, even the anger from heaven.

Pestilence is also one of the disasters that people fear. The plague in the Middle Ages took onethird of the lives in Europe at that time. This chilling disaster also left countless impressive works of art. The Plague Hospital (Figure 4) by Francisco Goya depicts the despair brought by the plague to the world. The plague patients lying on the ground can hardly recognize their facial language in the dark interior space. The dim tone controls the whole painting as if death had taken over everything. People's body movements show despair, numbness and pain, and at the end of the picture, that window with strong light was close at hand, as if it had been pulled away in the dark, indicating that hope has been far away from these unfortunate people, life is coming to an end, and death is near.
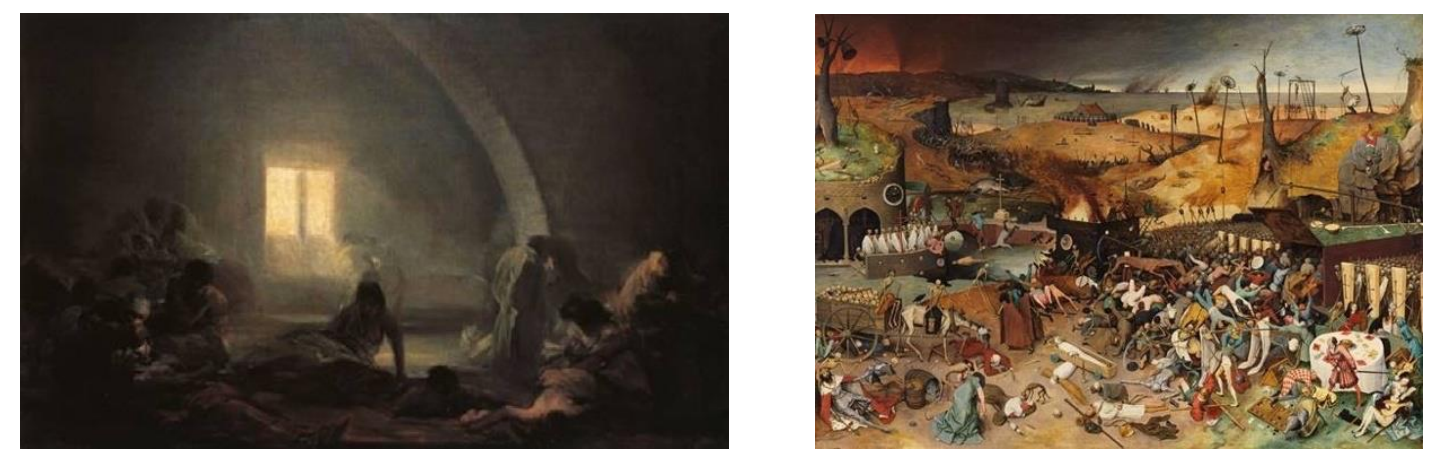

Figure 4. Francisco Goya, Plague Hospital

Figure 5. Bruegel Pieter, The Victory of Death

In Peter Bruegel's work- the Victory of Death (Figure 5), the dead skeletons take over the world. They sweep the world. Everywhere they pass, there are smoke, withered vegetation and corpses everywhere. The smoke in the scene seems to record the spread of disaster. The soldiers, nobles, friars and civilians in the foreground of the painting have their own characteristics. Life is being carried away by death in different ways. Those who are still alive are forced to the right side of the scene. They show their desperate body language. The man who prays with both hands looks at the sky tightly, as if questioning where God's salvation is. However, what is more, despairing is that the army of skeletons is gradually pouring in in the painting's perspective, and their brutal killing is imminent.

In Chinese traditional art, few works directly bring disaster to the public's vision. Chinese art tends to do artworks into a kind of ideological object with special value, which can have the 
aesthetic feeling of the art form and outstanding techniques and have the functions of calling for unity, inspiring labour, and serving politics. This is a kind of art from the collectivist appeal.

There are different opinions on the origin of art, but few of them are forced, task-based or forced to do so. When a primitive tribe first steps forward and dances with his own judgment of beauty, it is a kind of free release; when a young child first picks up a paintbrush and outlines his own image of beauty on paper, it is also unrestrained the manifestation of freedom. Therefore, there is a conflict and contradiction in art: the contradiction between "art is the manifestation of freedom" and "art is a derivative of a certain will". Of course, it must be noted here that this is not to deny that some creators just have the internal power of a certain special will.

It is obvious that Chinese art does not like to move disasters to the public view. There are few disastrous descriptions of "this shore" of life in artworks, such as art, design, film and television, while the opposite "other shore" of death is described as a frightening world. The royal nobles try to show the prosperity of the prosperous times with the wealth of flowers and birds. However, the disaster as the opposite is suspected of reflecting the decline of the country and the resentment of the people. The literati and officialdom like to metaphor the noble character and cultivation between the landscape and plants to show their moral sense, knowledge, talent and philosophy. The disaster theme is far from the core of literati painting; in addition, few folk painters to the art form with disaster theme; art tends to present a form and content of beauty. In the rare disastrous description, the artist constantly conveys scenes of salvation heroes coming down to earth like gods to relieve and eliminate evil in the form of drama. It seems that all disasters in China are so small and vulnerable: countless floods, droughts, plagues, locusts recorded in history. They have not been able to turn a wave in the history of Chinese art.

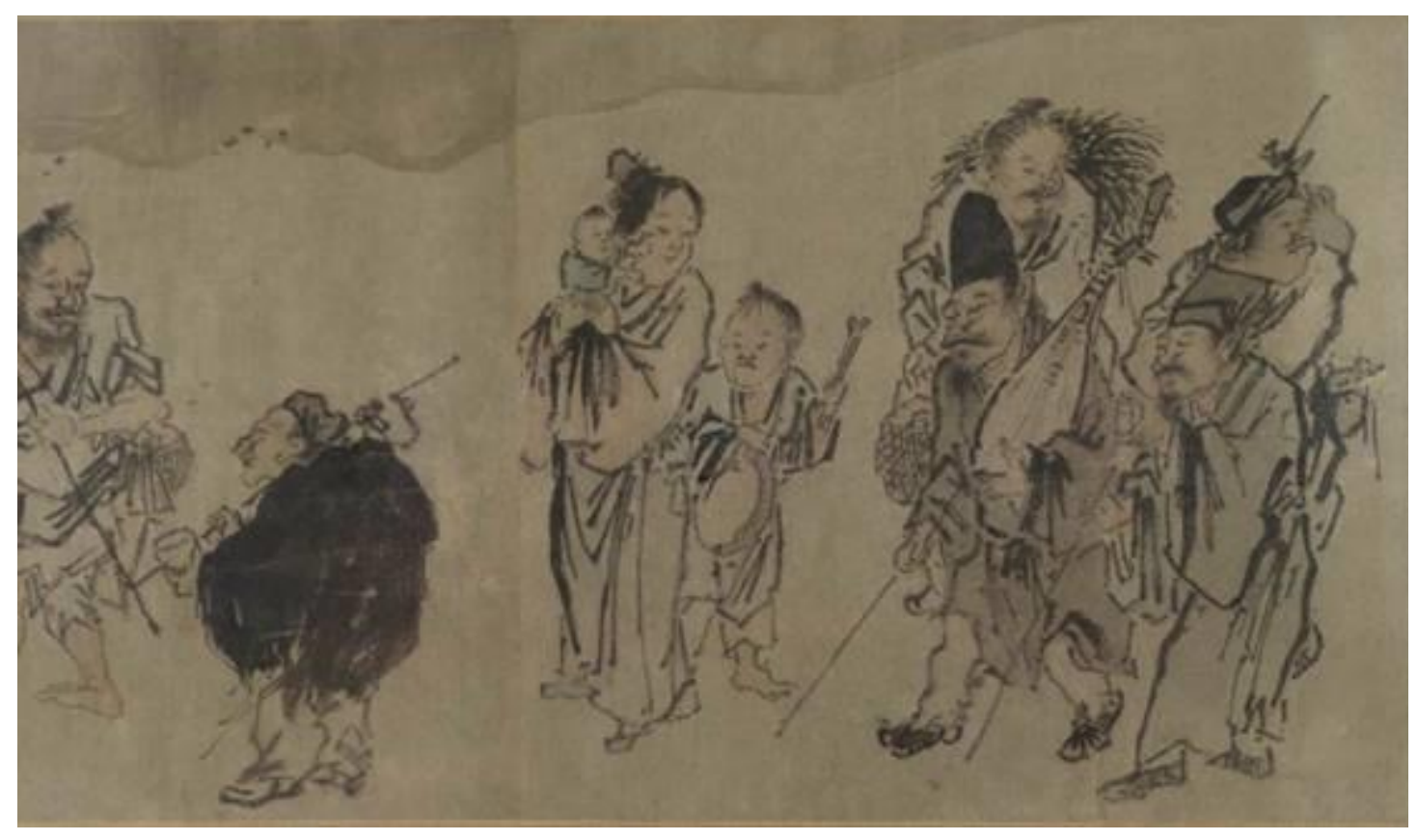

Figure 6. Wu Wei (Ming Dynasty), the Picture of Refugees (partial) 
Wu Wei's Picture of Refugees (Fig. 6) is a rare depiction of disaster left over from history. In the painting, the peasants fleeing from famine are depicted as images full of playful and abusive meanings. The tragic image of the people at the bottom of society becomes as the characters played in modern stage plays. The refugees are still struggling in exile. They are in groups of three or two, talking with each other, playing musical instruments, and even performing acrobatics attracted the ragged refugees around to stop and look back, as if the disaster had not affected their normal life much. Wu Wei's works show the top-down elite's overlooking of the people at the bottom, depicting the disaster scene conceived by the elite with a sense of the impact of the disaster out of reality. His paintings do not show too much sympathy for the real tragedy but a rational relationship between people and society. Even in the disaster, he does not lose his spiritual pleasure to please admirers.

Obviously, through the analysis of the creation of disaster theme in eastern and western art, it is not difficult for the viewer to find out the different attitudes of China and the west towards disaster: in the works of Western artists, disaster shows its terrible fangs, which makes the viewer face the consequences of disaster directly, and then reflect on their own behaviour; in Eastern art, the horror of disaster is often deliberately avoided by the creator. In the Eastern land, where the collective sense is stronger, people are more willing to accept the ideal spiritual home of harmony and peace. The reason is that the Oriental people's yearning for the ideal world is buried in their hearts. The shaping of this world is inseparable from the joint efforts of every link in society. Collective consciousness makes it difficult to find a place for ideas potentially not conducive to collective prosperity. The ethical philosophy of Chinese people requires that the formulation of social norms should have the ideal of harmony. Therefore, few scientific and logical arguments are closely related to each other, such as those in western philosophy. This gene engraved in the blood acts on art, making Oriental Art and Western art have different internal driving forces from the root.

\section{$5 \quad$ Reflection and Transcendence}

The artistic creation of disaster theme is conducive to the expression of human nature, life, collective, nation, country, and other feelings to realize the thinking of art communication. Meanwhile, it shall be the eternal theme of artistic creation to excavate and actively promote the humanistic feelings in the disaster (Zhang \& Zelin, 2009). Based on spiritual thinking is one of the most important links in modern art, and it is also a necessary condition to promote the harmonious coexistence of society. Thus, the artistic creation of the disaster theme needs to be affirmed by the public. However, in Chinese land, disaster is always a pain that the public is unwilling to mention. People prefer to believe that the future is beautiful. Disaster needs to be avoided through various efforts. The art of disaster theme is not of great practical significance. At 
the same time, too much depiction of disaster is often regarded as an unfavourable potential danger of promoting the harmony and stability of the collective, society and country.

The Stoic philosopher Lucius Annaeus Seneca (about 4-65 BC) believed that a person who had not experienced disaster was equivalent to losing his understanding of the other half of life, which was obviously a shallow life. Seneca affirms the value of disaster. He believed that disaster had the value of improving a person's moral character. This is what Seneca said: the disaster is an opportunity for virtue; what really matters is not what you bear, but how you bear it; only extreme pain is the last liberator of the spirit, and only this kind of pain forces us to have a thorough understanding.

But this is not to deny the Chinese attitude towards disasters. Chinese attitude towards disasters and the spiritual guidance given by disaster themes have played a good role in promoting social unity, collective honour and disgrace, and citizens' sense of security, equality, and happiness. China's response to disasters and pestilence, from the traditional avoidance of pestilence to current active prevention and treatment of pestilence, reflects a strong scientific and human culture. Behind this change is the great change in the world's understanding of pestilence, the relationship between man and pestilence, and nature (Yu, 2021). China pursues the principle of putting the collective interests first and expects the society to prosper together, which enables citizens to face disasters with confidence and confidence in the face of disasters without losing hope in them. Thus, disaster art is often accompanied by heroes' sacrifice, selfless dedication, ceaseless struggle, and collectivism when disaster comes. The reason is precise because of the Chinese people's inner understanding of the harmonious coexistence between man and the universe, which makes people realize that they are small and need to gather more strength to face difficulties.

Moreover, for death, the Chinese think that it is the end of life. For westerners, the strong religious consciousness makes them believe that they will face the trial from another world after death. When death is faced squarely, it becomes less terrible. Therefore, it is not difficult to find that the root of the different attitudes of the East and the west towards the disaster lies in the differences in the cognition of "the other side" in the human brain, that is, the vision of the Chinese people tends to focus on the "this side" of life, while the Westerners trust to find their own destination on the other side. In the face of disaster, Chinese artists put themselves in the collective and submit their strength to the collective consciousness. People will defeat the volitional and selfless hero shaping of disaster is the eternal theme of Chinese people in the face of disaster.

\section{Conclusion}

In all aspects of the social division of labour, art cannot immediately affect the face of disaster, but it's obviously not the responsibility that art should bear. Art cannot control the progress of a 
disaster, but it has the potential to change our attitude towards disaster. Art is the objective presentation of the creator's thinking, and its display has strong communication, which is the reason. The media have similarities, but the current art creation is obviously due to a variety of reasons, in the face of disasters, showing a trend of "art media", of course, this is not a complete negation of this behaviour, in a special period, people want to overcome the disaster, is bound to gather the collective strength, through the multi-faceted encouraging voice to work together. Through these obviously, it plays a positive role in the national cohesion of a country and should be advocated in a special period. However, compared with the media's inherent "instantaneity" and "freshness", artistic creation also can reflect on things in the later stage. This "lagging" feature is different from that of the news media. Should art have more expression space instead of too much guidance or ideological interference? The enlightenment significance in art should not be a kind of bondage, which makes art creators fall into a passive situation. Instead, it should be guided by a multi-level, multi-directional three-dimensional vision so that artists can face the disaster directly, rather than praise or emphasize moral education. This is because the disastrous narrative enables people to understand the world more comprehensively. What artists lack now is the courage and wisdom of free expression. In modern China, the level of science and technology and medical treatment is far higher than before. People have more effective response measures to plague and disaster, but the culture of introspection and criticism is still relatively poor. The plague is frightening, but it has also become the driving force of human progress. History is often tortuous, and disasters are inevitable natural phenomena. Human beings analyze disasters from the perspective of natural science and study measures and governance programs to deal with disasters, which has a distinct significance for the progress of human material civilization. But at the same time, we also need to pay attention to the construction of disaster culture, which can also obtain the path of sustainable human development from another perspective to further promote the progress of human civilization.

\section{REFERENCES}

[1] Askar Nur. (2021). Cultural Reproduction in the Charles Dickens' Novel Great Expectations (Pierre-Felix Bourdieu Theory). International Journal of Culture and Art Studies, 5(01), 10-20. doi: https://doi.org/10.32734/ijcas.v5i1.4866

[2] Ernst Cassirer. (1985). An Essay on Man. Shanghai, , China: Shanghai Translation Publishing House.

[3] Li, S.(2011). Commentary of Zuo Authentic. Beijing, China: Huaxia Press.

[4] Li, W.(2012). Differences between Chinese and Western Sense of Heroes under Comparative Perspective. Academic Research, 19(04), 99-101. doi: CNKI:SUN:YXST.0.2012-04-027.

[5] Tang, D. X. (2011). Why Research Disasters and Epidemic Culture?- Exploring the Root Cure Method of Current Disasters and Epidemic. Journal of Southwest University of Nationalities, 32(11), 21-26. doi: 10.3969/j.issn.1004-3926.2011.11.003 
[6] Yu, X.Z.(2021). A Preliminary Study of Plague Culture in Traditional Chinese Plague Narration. Historiography Collection, 65(02),19-27. doi: CNKI:SUN:SHXZ.0.202102-005.

[7] Zhang, S. S., Song L.. (2018). China Folk Culture Cultural Development Report 2016. Jinan, China: Shandong University Press.

[8] Zhang, Y.M. \& Zelin, D. (2009, June 5). Art Does Not Only Records Disasters, But Also Discovers Life. China Art Daily, p.1. doi: 10.28155/n.cnki.ncysb.2009.000999

[9] Zhi, Y.(2011). Disaster Art in the Post Metaphysical Era: on The Significance, Depth and Aesthetic Character of Chinese Contemporary Disaster Literature and Art. social science research, 32(02), 20-26. doi: CNKI:SUN:SHYJ.0.2011-02-006. 